\title{
Effect of drains on the distribution of zooplankton at the southeastern part of Lake Manzala, Egypt.
}

\author{
Hesham R. Abdel Mola*1 and Mohamed Abd El-Rashid ${ }^{2}$ \\ 1- National Institute of Oceanography and Fisheries, 101, Kasr El-Einy St, Cairo, Egypt. \\ 2- Marine chemistry Lab, Department of zoology, faculty of science, Al-Azhar Univ., Egypt. \\ Email:hesham_reda06@yahoo.com
}

\section{ABSTRACT}

The drains of Lake Manzala play important role in the distribution of zooplankton, especially at the southeastern part of the lake. Samples were collected from six stations at southeastern sector of the lake from August, 2009 to May, 2010. Physico-chemical parameters and zooplankton were analyzed following APHA (1992). Six groups of zooplankton were recorded; Rotifera constituted the main dominant group in the lake contributing $80.04 \%$ of the total zooplankton population followed by Copepoda (17.29 \%), Protozoa (1.35\%) and Cladocera (1\%). Ostracoda and Nematoda were the less dominant groups forming 0.20 and $0.12 \%$ respectively. The Highest density of zooplankton was recorded at Ibn Salam Station (4519665 Org. $/ \mathrm{m}^{3}$ ) during spring due to the effect of wastewater discharge, rich in nutrients, through 3 main drains at this area, while the lowest abundance was recorded at ElQaboti Station (17666 Org. $/ \mathrm{m}^{3}$ ) during winter. The lowest average numbers of total zooplankton was recorded at Bahr El-Bakar Station (160840 Org. $/ \mathrm{m}^{3}$ ). This due is to discharging sewage from Bahr El-Bakar drain which considered the main source of pollution in the lake.

Keywords: water quality, zooplankton, Lake Manzala

\section{INTRODUCTION}

Lake Manzala, the largest and the most productive of the Egyptian Delta lakes, is considered as one of the essential sources of fisheries in Egypt. The lake is situated in the north-eastern extremity of the Nile Delta. It lies between longitude $31^{\circ}: 45^{\backslash}$ $32^{\circ}-50^{\backslash} \mathrm{E}$ and latitude $31^{\circ}$ : 00- 31 $1^{\circ}$ : 35 $\mathrm{N}$ (El-Bokhty, 1996 \& Mageed, 2008). The Lake is bounded by the Mediterranean Sea to the North, Suez Canal to the East, and Damietta Branch of the River Nile to the West (Fig. 1). The southern shores of the lake form the north boundary of Dakahiliya and Sharkiya Governorates. The lake is connected with the Mediterranean Sea by a narrow sandy fringe namely; El-Gamil, New El-Gamil, El-Boughdady and New Damietta Boughases (El-Enany, 2004). The lake is also connected with Suez Canal at Qaboti, few kilometers to the South of Port Said. The islands in the lake divided it into several regions known to the local fishermen as Bohours. Each of them has more or less distinctive ecological character (Shehata, 1982; El-Bokhty, 1996). The largest drain, Bahr El-Bakar drain, is started from East Cairo and goes toward north through Nile Delta carrying human, industrial wastes and agriculture drainage water into the lake from five governorates into the lake through two branches. The first, Old Bahr El-Bakar Drain which poured in El-Genka area and the second is New Bahr El-Bakar which poured in Bahr El-Bashtir (Khalil, 1990a; El-Enany, 2004; Mageed, 2008). Hadous, Ramsis and Bahr El-Bakar drains contributed about $75 \%$ of the total annual drainage water at the southern sector of Lake El-Manzalh and the Lack is considered as a sink for the disposing industrial and human wastes (Abdel-Satar, 2001). 
Zooplankton is good indicators of particular environmental conditions or their change as revealed by many studies. Zooplankton has been used as indicators of water quality. Some species flourish in highly eutrophic waters, while others are very sensitive to organic or chemical wastes (Mola, 2011). Rotifers constituted the main food of Cichlid species (Hegab, 2010). Rotifers, especially Brachionus, constitute an important link in the food chains of inland waters. They are considered preferred food for many fish larvae (Guerguess, 1993). Zooplankton Lake Manzala was studied by El-Maghraby et al. (1963), Guerguess (1979), MacLaren (1982), Khalil \& El-Awamri (1988); Khalil (1990b); Guerguess (1993), El-Sherif et al. (1994), Khalifa \& Mageed (2002) and Mageed (2008). The aim of the present work is to study the effect of drains on distribution of zooplankton in southeastern part of the lake and the physicochemical parameters correlated with the distribution of the most dominant species and groups of zooplankton.

\section{MATERIAL AND METHODS}

\section{Sampling stations:}

Six stations were selected (Fig.1) in the south-eastern part of the lake that affected by many drains:

1- Station I (Qaboti): Few kilometers from Port Said City.

2- Station II (El-Bashtir): Located in Bahr El-Bashtir 7 km from Qaboti.

3- Statiom III (Bahar El-Bakar): at the discharged point of New Bahr El-Bakar drain.

4- Station IV (El boom): at the main channel West of Bahr El-Bakar drain.

5- StationV (Ibn Salam): at Bahr El-Genka in front of Ibn Salam island. Three main drains (Hadous, Ramsis and Old Bahr El-Bakar) discharged near from this area.

6- Station VI (El-Matariya): It is located in the front of El-Matariya City.

\section{Collection and analysis of samples:}

Water samples and zooplankton samples were collected seasonally during the period from August, 2009 to May, 2010. Air and water temperature were measured in shade during the time of sampling using a mercury thermometer graduated to $100{ }^{\circ} \mathrm{C}$. Transparency of water column was determined using black and white enamel coated Secchi Disk with a diameter of $20 \mathrm{~cm}$. Electrical conductivity (E.C) was measured by the conductivity meter. The results were expressed as $(\mathrm{mS} / \mathrm{cm})$. Hydrogen ion concentration $(\mathrm{pH})$ was directly measured by $\mathrm{pH}$ meter (model Jenway 3150 ). All the chemical parameters were determined according to APHA (1992). Zooplankton was collected by filtration of 30 Litters from the surface with a plankton net of $55 \mu, 25$ $\mathrm{cm}$ diameter and $80 \mathrm{~cm}$ length. All samples were immediately fixed with $4 \%$ formalin. In the laboratory, the samples were examined with Optic Research Microscope. Three subsamples (one $\mathrm{ml}$ for each) of the homogenized plankton samples were transferred to a counting cell and the different plankters were counted. Planktonic organisms were classified and identified according to Edmondson (1966); Pontin (1978) and Shehata et al. (1998 a \& b). Cluster analysis (Similarity index) and correlation coefficient were carried out on data at selected stations by MINITAB 12 under Windows. 


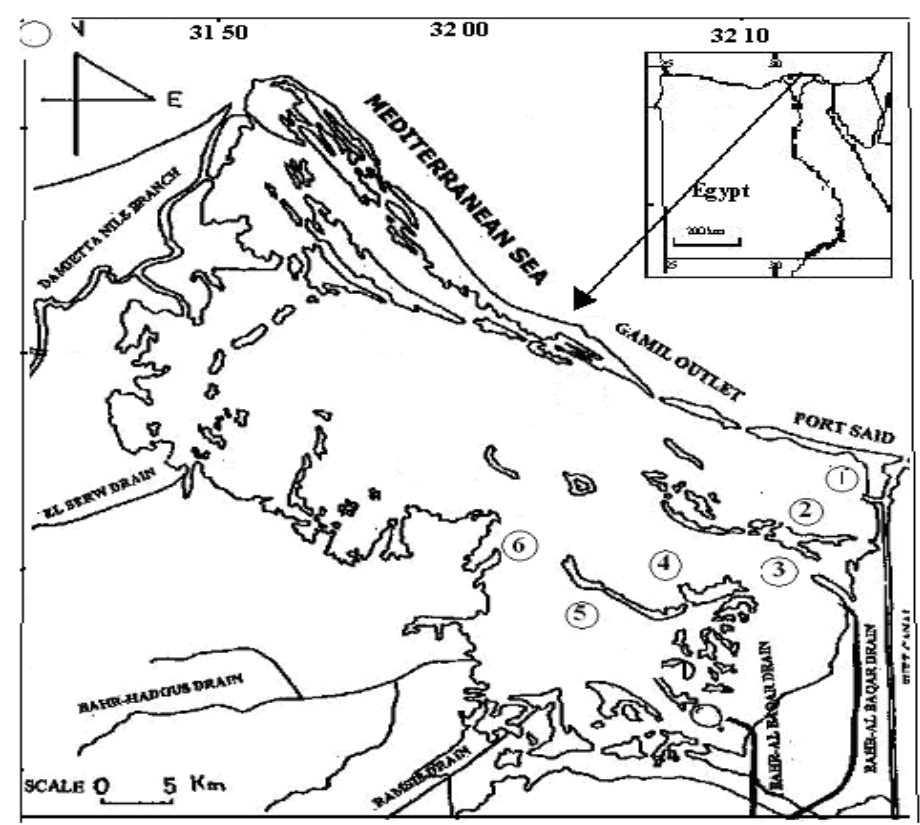

Fig.1: A map of Lake Manzala showing sampling stations.

\section{RESULTS AND DISCUSSION}

\section{Water quality:}

The variations of water temperature (Table 1) showed agreement with air temperature. The highest temperature was recorded during summer $\left(34{ }^{0} \mathrm{C}\right)$ and the lowest during winter $\left(13{ }^{0} \mathrm{C}\right)$.

Table 1: Physico-chemical parameters in the selected stations of Lake Manzala during the period from August, 2009 to May, 2010.

\begin{tabular}{|c|c|c|c|c|c|c|c|c|c|c|}
\hline Seasons & Stations & $\begin{array}{l}\text { water } \\
\text { temp. } \\
\left({ }^{0} \mathrm{C}\right)\end{array}$ & $\begin{array}{l}\text { Trans. } \\
(\mathrm{Cm})\end{array}$ & $\begin{array}{l}\text { E.C } \\
(\mathrm{mS} / \mathrm{cm})\end{array}$ & $\mathrm{pH}$ & $\begin{array}{l}\text { D.O } \\
(\mathrm{mg} / \mathrm{l})\end{array}$ & $\begin{array}{l}\text { COD } \\
(\mathrm{mg} / \mathrm{l})\end{array}$ & $\begin{array}{l}\mathrm{CO}_{3} \\
(\mathrm{mg} / \mathrm{l})\end{array}$ & $\begin{array}{l}\mathrm{HCO}_{3} \\
(\mathrm{mg} / \mathrm{l})\end{array}$ & $\begin{array}{l}\mathrm{Cl}^{-2} \\
(\mathrm{mg} / \mathrm{l})\end{array}$ \\
\hline \multirow{6}{*}{ Summer } & I & 32 & 37 & 8.21 & 8.21 & 5.10 & 8.8 & 0.0 & 256.0 & 2.80 \\
\hline & II & 32 & 24 & 5.15 & 7.67 & 5.00 & 5.9 & 0.0 & 464.0 & 1.73 \\
\hline & III & 31 & 21 & 5.21 & 8.14 & 2.20 & 17.6 & 0.0 & 696.0 & 1.76 \\
\hline & IV & 31 & 22 & 6.64 & 7.91 & 4.20 & 12.2 & 0.0 & 768.0 & 2.21 \\
\hline & $\mathrm{V}$ & 31 & 26 & 4.78 & $\begin{array}{l}7.68 \\
\end{array}$ & 4.40 & 18.4 & 0.0 & 494.0 & 1.56 \\
\hline & VI & 32 & 29 & 2.47 & 7.76 & 4.90 & 19.4 & 0.0 & 324.0 & 0.84 \\
\hline \multirow{6}{*}{ Autumn } & I & 23 & 44 & 9.56 & 8.15 & 6.40 & 12.8 & 8.8 & 244.0 & 2.95 \\
\hline & II & 22 & 40 & 7.52 & 7.74 & 5.50 & 6.4 & 12.0 & 418.0 & 2.26 \\
\hline & III & 23 & 36 & 7.79 & 7.66 & 2.90 & 16.0 & 0.0 & 640.0 & 2.31 \\
\hline & IV & 21 & 37 & 9.24 & 7.81 & 6.20 & 14.4 & 10.0 & 706.0 & 2.94 \\
\hline & $\mathrm{V}$ & 22 & 46 & 7.22 & 7.62 & 6.10 & 8.2 & 8.0 & 502.0 & 2.31 \\
\hline & VI & 23 & 45 & 3.96 & 7.43 & 6.30 & 8.4 & 8.0 & 309.0 & 1.38 \\
\hline \multirow{6}{*}{ Winter } & I & 16 & 22 & 5.68 & 8.64 & 3.63 & 17.6 & 17.6 & 210.0 & 1.95 \\
\hline & II & 16 & 21 & 8.10 & 8.30 & 5.18 & 7.2 & 7.2 & 368.0 & 2.73 \\
\hline & III & 14 & 17 & 4.36 & 7.92 & 2.79 & 9.6 & 9.6 & 618.0 & 1.43 \\
\hline & IV & 15 & 19 & 4.66 & 8.27 & 2.98 & 4.6 & 4.6 & 682.0 & 1.49 \\
\hline & $\mathrm{V}$ & 15 & 20 & 3.42 & 7.89 & 2.19 & 16.0 & 16.0 & 432.0 & 1.10 \\
\hline & VI & 16 & 22 & 2.35 & 7.74 & 1.50 & 12.8 & 12.8 & 300.0 & 0.75 \\
\hline \multirow{6}{*}{ Spring } & I & 22 & 40 & 19.89 & 7.97 & 5.50 & 17.6 & 12.0 & 180.0 & 6.83 \\
\hline & II & 22 & 45 & 3.27 & 7.04 & 4.90 & 12.8 & 12.0 & 152.0 & 1.12 \\
\hline & III & 23 & 32 & 3.36 & 6.98 & 2.10 & 29.9 & 0.0 & 180.0 & 1.14 \\
\hline & IV & 23 & 47 & 5.67 & 7.23 & 5.30 & 7.9 & 8.0 & 172.0 & 1.94 \\
\hline & V & 23 & 49 & 4.17 & 7.41 & 5.40 & 8.8 & 10.0 & 168.0 & 1.41 \\
\hline & VI & 22 & 46 & 2.39 & 7.49 & 5.90 & 10.7 & 8.0 & 170.0 & 0.81 \\
\hline
\end{tabular}


Transparency ranged between $17 \mathrm{~cm}$ at Bahr El-Bakar station during winter due to the effect of drain which carries high amount of organic and suspended matter in this mixing point, while the highest reading was recorded at Ibn salam station (49 $\mathrm{Cm}$ ) during spring. Also, $\mathrm{pH}$ recorded its lowest value (6.98) at Bahr El-Bakar station during spring; the relative decrease of $\mathrm{pH}$ values in this station is due to the effect of Bahr El-bakar drain (Abdel-Satar, 2001) and the highest (8.64) was recorded at Qaboti Station during winter. The amount of dissolved oxygen required for maintenance of healthy biota must be over $5 \mathrm{ml} \mathrm{O}_{2} / \mathrm{L}$ (Train, 1979). Dissolved oxygen recorded its minimum values at Bahr El- Bakar being 2.20, 2.902 .79 and $2.10 \mathrm{mg} / \mathrm{l}$ during summer, autumn, winter and spring, respectively. This may be attributed to the effect of pollution by sewage and agricultural wastes discharged, as well as, biochemical composition of organic matter leads to increasing ammonia and sulphids causes mineralization of organic matter during eutophication and induced enormous oxygen depletion (Emam, 2006). The highest positive correlation between phsicochemical parameters (Table 2) was recorded between dissolved oxygen and transparency $(\mathrm{r}=0.71)$. Generally, the highest values of chemical oxygen demand (COD) was recorded at Bahr El-Bakar Station due to the high load of organic matter from the drain. Bicarbonate concentrations ranged between 152-706 mg/l. Abdel satar (2001) recorded similar observations and mentioned that these highest values of bicarbonate considered favorable conditions for fish production.

Table 2: The correlation coefficient matrix between some physico-chemical parameters at Lake El-mazalah during the period from August, 2009 to may, 2010.

\begin{tabular}{|l|c|c|c|c|}
\hline Parameters & Water temp. & Trans. & E.C & pH \\
\hline D.O & 0.25 & 0.71 & 0.36 & -0.11 \\
\hline pH & 0.02 & 0.20 & 0.33 & \\
\hline E.C & 0.02 & 0.20 & & \\
\hline Trans. & 0.15 & & & \\
\hline
\end{tabular}

Nutrient salts were high in the lake. Nitrite, nitrate, silicate, total phosphorus and sulphate were analysis at the selected stations. The discharging points at the drain recorded the highest values of nutrients especially at the New Bahr El-Bakar Station. This may be due to the highly polluted sewage and agricultural wastes, which discharged at this station through the New Bahr El-Bakar Drain. It was fluctuated between 1.32-89.91 $\mu \mathrm{g} / \mathrm{l}, 0.29-2.22 \mu \mathrm{g} / \mathrm{l}, 0.85-7.82 \mathrm{mg} / \mathrm{l}, 353.66-1395.62 \mu \mathrm{g} / \mathrm{l}$ and 22.61-357.43 mg/l for nitrite, nitrate, silicate, total phosphorus and sulphate respectively. El-Enany (2004) mentioned that the southeastern part of Lake Manzala highly enrichment with nutrient salts than any other part of the lake due to the effect of drains at this part. Major cations were showed wide variations at the southeastern part of the lake. It was fluctuated between $280.47-821.13 \mathrm{mg} / \mathrm{l}, 12.12-44.39 \mathrm{mg} / \mathrm{l}$ and 30.46-135.22 mg/l for sodium, potassium and calcium respectively. Its lowest value at El-Matariya Station, while the highest values were recorded at Qaboti station; this may be due to exchange of saline water from Suze Canal through Qaboti Channel. Major cations recorded were increasing with increasing of nutrient salts (Tables 3\&4). This agrees with Abdel Satar (2001) recorded high positive correlation between major cations and nutrient salts. The data of correlation coefficient revealed that there is appositive correlation between total Brachionus and water temperature, transparency and dissolved oxygen, while a negative correlation with $\mathrm{pH}$ and electrical conductivity (Table 2). 
Table 3. Seasonal variations of major cations (sodium, potassium \& calcium) and nutrient salts (nitrite, nitrate, silicate, total phosphorus and sulphate) in the selected stations of Lake Manzala during the period from August, 2009 to May, 2010.

\begin{tabular}{|c|c|c|c|c|c|c|c|c|c|}
\hline Seasons & Stations & $\begin{array}{c}\mathrm{NO} 2 \\
(\mu \mathrm{g} / \mathrm{l})\end{array}$ & $\begin{array}{l}\mathrm{NO} 3 \\
(\mu \mathrm{g} / \mathrm{l})\end{array}$ & $\begin{array}{c}\mathrm{SiO} 3 \\
(\mathrm{mg} / \mathrm{l})\end{array}$ & $\begin{array}{c}\text { T.PO4 } \\
(\mu \mathrm{g} / \mathrm{l})\end{array}$ & $\begin{array}{c}\mathrm{SO} 4 \\
(\mathrm{mg} / \mathrm{l})\end{array}$ & $\begin{array}{c}\mathrm{Na}^{+} \\
(\mathrm{mg} / \mathrm{l})\end{array}$ & $\begin{array}{c}\mathrm{K}^{+} \\
(\mathrm{mg} / \mathrm{l})\end{array}$ & $\begin{array}{c}\mathrm{Ca}^{+2} \\
(\mathrm{mg} / \mathrm{l})\end{array}$ \\
\hline \multirow{6}{*}{ Summer } & I & 7.24 & 0.09 & 0.85 & 353.66 & 42.69 & 714.32 & 26.64 & 96.10 \\
\hline & II & 80.42 & 2.94 & 5.82 & 803.02 & 34.03 & 514.82 & 21.77 & 41.62 \\
\hline & III & 89.45 & 3.27 & 5.72 & 324.53 & 42.97 & 632.72 & 23.35 & 51.23 \\
\hline & IV & 8.03 & 0.29 & 4.83 & 727.85 & 33.90 & 472.31 & 20.05 & 28.86 \\
\hline & $\mathrm{V}$ & 15.83 & 0.58 & 4.46 & 466.11 & 22.61 & 416.32 & 19.57 & 54.43 \\
\hline & VI & 48.72 & 1.79 & 5.47 & 497.81 & 32.36 & 372.79 & 18.19 & 32.06 \\
\hline \multirow{6}{*}{ Autumn } & I & 41.54 & 1.68 & 1.22 & 702.04 & 159.80 & 643.69 & 21.11 & 135.22 \\
\hline & II & 27.54 & 1.25 & 3.88 & 1235.92 & 139.71 & 511.51 & 16.42 & 48.96 \\
\hline & III & 25.69 & 1.29 & 3.51 & 1233.96 & 142.57 & 551.74 & 16.42 & 66.91 \\
\hline & IV & 50.76 & 2.15 & 3.62 & 568.46 & 154.19 & 620.70 & 19.16 & 39.17 \\
\hline & V & 58.58 & 2.23 & 3.92 & 776.00 & 166.20 & 574.73 & 16.03 & 55.49 \\
\hline & VI & 48.09 & 2.15 & 2.90 & 251.92 & 148.41 & 280.47 & 12.51 & 35.90 \\
\hline \multirow{6}{*}{ Winter } & I & 41.54 & 1.68 & 5.42 & 929.72 & 150.36 & 821.13 & 44.39 & 44.89 \\
\hline & II & 27.54 & 1.25 & 7.82 & 1073.42 & 184.96 & 816.11 & 25.42 & 44.89 \\
\hline & III & 25.69 & 1.29 & 6.84 & 1082.98 & 196.33 & 723.01 & 30.89 & 52.91 \\
\hline & IV & 50.76 & 2.15 & 5.88 & 621.47 & 229.79 & 574.73 & 19.55 & 25.65 \\
\hline & $\mathrm{V}$ & 58.58 & 2.22 & 5.90 & 863.66 & 207.50 & 413.80 & 15.25 & 83.37 \\
\hline & VI & 48.09 & 2.15 & 4.31 & 575.08 & 193.69 & 317.21 & 12.12 & 30.46 \\
\hline \multirow{6}{*}{ Spring } & I & 89.91 & 1.63 & 2.68 & 485.89 & 357.43 & 722.69 & 29.41 & 58.36 \\
\hline & II & 2.66 & 1.21 & 2.39 & 721.66 & 186.27 & 701.15 & 26.28 & 65.82 \\
\hline & III & 1.32 & 1.34 & 4.99 & 1395.62 & 173.44 & 693.21 & 25.54 & 74.41 \\
\hline & IV & 4.21 & 1.81 & 3.22 & 972.23 & 182.34 & 498.31 & 20.92 & 69.30 \\
\hline & V & 3.78 & 1.98 & 3.98 & 632.51 & 196.22 & 466.06 & 19.62 & 71.32 \\
\hline & VI & 3.12 & 1.76 & 4.24 & 842.34 & 201.56 & 411.39 & 18.82 & 72.62 \\
\hline
\end{tabular}

Table 4. Correlation coefficient between physico-chemical properties and the most dominant groups and species of zooplankton during the period from August, 2009 to May, 2010.

\begin{tabular}{|c|c|c|c|c|c|c|c|c|c|c|c|c|}
\hline Parameters & $\begin{array}{c}\text { T. } \\
\text { Zoo }\end{array}$ & $\begin{array}{c}\text { T. } \\
\text { brach }\end{array}$ & $\begin{array}{c}\text { B. } \\
\text { ang. }\end{array}$ & B. calci & $\begin{array}{c}\text { T. } \\
\text { Copepoda }\end{array}$ & $\begin{array}{l}\text { Nuplius } \\
\text { larvae }\end{array}$ & $\begin{array}{c}\text { T. } \\
\text { Rotifera }\end{array}$ & Polyarthra & Philodina & $\begin{array}{c}T . \\
\text { Cladocera }\end{array}$ & $\begin{array}{c}\text { T. } \\
\text { protozoa }\end{array}$ & $\begin{array}{c}\text { T. } \\
\text { Nematoda }\end{array}$ \\
\hline water tem. & 0.2 & 0.2 & 0.1 & 0.3 & 0.2 & 0.0 & 0.0 & 0.1 & 0.0 & 0.0 & 0.1 & 0.2 \\
\hline E.C & 0.1 & -0.1 & -0.1 & -0.1 & -0.1 & 0.6 & 0.0 & 0.0 & -0.2 & 0.0 & -0.2 & -0.2 \\
\hline pH & -0.2 & -0.2 & -0.2 & -0.2 & -0.2 & 0.0 & -0.2 & -0.3 & 0.0 & 0.0 & -0.5 & -0.2 \\
\hline COD & -0.1 & -0.1 & -0.1 & 0.2 & 0.0 & 0.0 & -0.1 & 0.0 & -0.2 & 0.0 & 0.2 & 0.4 \\
\hline $\mathrm{CO} 3$ & 0.0 & 0.0 & 0.1 & -0.2 & 0.0 & 0.3 & 0.0 & 0.1 & 0.0 & 0.1 & -0.1 & -0.4 \\
\hline HCO3 & -0.3 & -0.2 & -0.2 & -0.1 & -0.2 & -0.5 & -0.2 & -0.5 & 0.2 & -0.3 & -0.3 & 0.2 \\
\hline Cl & 0.1 & -0.1 & -0.1 & -0.1 & -0.1 & 0.6 & 0.0 & 0.0 & -0.2 & 0.0 & -0.2 & -0.2 \\
\hline $\mathrm{Na}+$ & -0.1 & -0.2 & -0.1 & -0.2 & -0.2 & 0.3 & -0.1 & 0.0 & -0.2 & 0.0 & -0.1 & 0.1 \\
\hline $\mathbf{K}+$ & 0.0 & -0.1 & -0.1 & 0.0 & -0.1 & 0.2 & -0.1 & 0.1 & -0.3 & 0.0 & -0.1 & 0.0 \\
\hline Ca & 0.2 & 0.1 & 0.1 & 0.0 & 0.1 & 0.5 & 0.1 & 0.4 & -0.1 & 0.7 & 0.2 & -0.1 \\
\hline Mg & 0.4 & 0.3 & 0.3 & 0.2 & 0.3 & 0.6 & 0.3 & 0.6 & 0.0 & 0.1 & 0.4 & 0.1 \\
\hline NO2 & -0.2 & -0.3 & -0.2 & -0.2 & -0.3 & 0.1 & -0.2 & -0.2 & 0.0 & -0.1 & -0.4 & -0.1 \\
\hline NO3 & 0.0 & 0.0 & 0.1 & 0.1 & -0.1 & -0.6 & 0.0 & 0.1 & 0.3 & 0.0 & 0.1 & 0.0 \\
\hline $\mathrm{SiO} 3$ & -0.2 & -0.1 & -0.1 & 0.0 & -0.1 & -0.6 & -0.1 & -0.4 & 0.1 & -0.4 & 0.0 & 0.1 \\
\hline T.PO4 & -0.2 & -0.2 & -0.2 & -0.2 & -0.2 & -0.3 & -0.2 & -0.2 & 0.1 & 0.0 & 0.3 & 0.2 \\
\hline SO4 & 0.1 & 0.0 & 0.1 & -0.2 & 0.0 & 0.5 & 0.0 & 0.2 & 0.0 & 0.1 & 0.1 & -0.1 \\
\hline
\end{tabular}

\section{Abundance and seasonal variations of zooplankton:}

The highest density of zooplankton (Fig. 2) was recorded at Ibn Salam Station (4519665 Org. $/ \mathrm{m}^{3}$ ) during spring due to the effect of water discharge rich in nutrients through 3 main drains, while the lowest abundance was recorded at El-Qaboti Station 
(17666 Org. $/ \mathrm{m}^{3}$ ) during winter. At all stations, the lowest average numbers of total zooplankton (T.Z) was recorded at Bahr El-Bakar Station (160840 Org./ $\mathrm{m}^{3}$ ). This due to this station is considered discharged point for different sewage from Bahr El-Bakar drain. This discharging had an adverse impact on the communities of zooplankton, while there was a progressive improvement and gradual recovery away from the outlet of drains with the high nutrient, contents led to increasing of denisity at the east and west sides. At west side, T.Z was increased gradually at El-boom Station (266165 Org. $/ \mathrm{m}^{3}$ ) and reached its highest average number of zooplankton at Ibn salam Station (1515225 Org. $/ \mathrm{m}^{3}$ ), away from the mixing points of drains, then it decreased again under the effect of agricultural and sewage drains at El-Matariys Station (185924 Org. $\left./ \mathrm{m}^{3}\right)$. At the east side of New Bahr El-Bakhar Drain, T.Z increased gradually at El-Bashtir Station (348798 Org. $/ \mathrm{m}^{3}$ ) and increased again by about two folds away from mixing point of the drain at Qaboti Station (615238 Org. $/ \mathrm{m}^{3}$ ). Mageed (2008) mentioned that the highest denisity of zooplankton is due to the drainage water discharged into the lake.

Rotifera constituted the main dominant group in the lake contributing about $80.04 \%$ (average 513306 Org. $/ \mathrm{m}^{3}$ ) of the total zooplankton population, followed by Copepoda (17.29 \%), Protozoa (1.35\%) and Cladocera (1\%) (Fig.3). Ostracoda and Nemadoda were considered the less dominant groups forming 0.20 and $0.12 \%$ respectively. During the present study, 46 species was recorded, Rotifera recorded the highest number of species (33 species) followed by Cladocera (7 species) and Protozoa (5 species) then Copepoda (one species) in addition to free living nematods and ostracodes. The dominance of Rotifera at investigated area may be due to their relatively short life cycle period compared to the larger crustacean zooplankton (Van Dijk and Van Zanten, 1995) or due to their ability to reproduce over a wide range of temperature (Galkovskaja, 1987). Rotifera had a positive correlation (0.3) with transparency and $\mathrm{Mg}$, while weak correlation with other parameters.

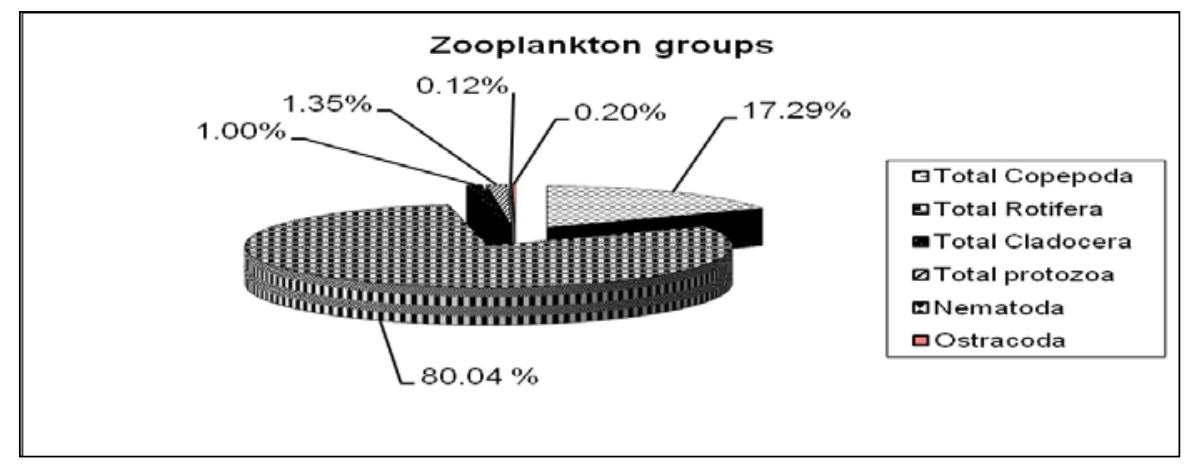

Fig. 2: Percentage composition of zooplankton groups in Lake Manzala during the 2009/2010.

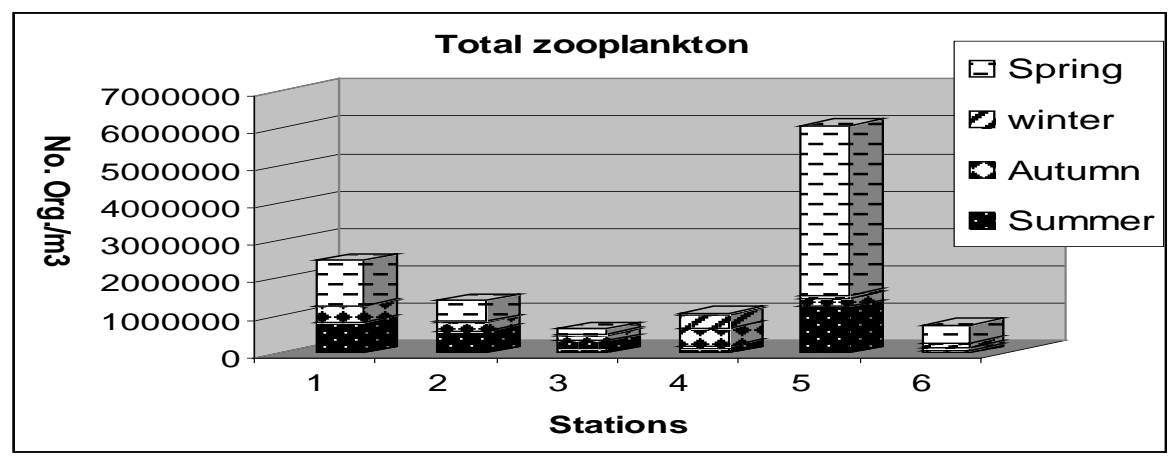

Fig. 3: Seasonal variation of total zooplankton recorded at the selected stations of the southeastern part of Lake Manzala during the period from August, 2009 to May, 2010. 
Brachionus sp. was the major component of zooplankton in the lake, constituting $74.8 \%$ of the total rotifers and $59.87 \%$ of the total zooplankton. It was represented by 7 species which are; Brachionus angularis, B. budapestinensis, $B$. calyciflorus, B. caudatus, B. Plicatilis, B. urceolaris and B. quadridentatus. The presence of Brachionus angularis and B. calyciflorus with high composition indicates eutrophication of Lake Manzala (Mageed, 2008). Rotifers, especially Brachionus plicatilis formed the most dominant species in the Eutrophic water bodies which referred to the influence of Eutrophication (Ahamed et al., 2011). Mageed (2008) and Ahmad et al. (2011) stated that the presence of more than 5 species Brichionus referring that to the eutrophication of water bodies. The highest abundance of Brachionus sp. was recorded at Ibn Salam Station (4227493 Org. $/ \mathrm{m}^{3}$ ) during summer due to the effect of water discharge rich in nutrients through 3 main drains (Hadous, Ramsis and Old Bahr El-Bakar ) near this area. Khalifa (2000), Bedair, (2003) and Emam, (2006) mentioned that, genus Brachionus has ability to tolerate the pollution. The lowest abundance was recorded at El-Qaboti Station (333 Org. $/ \mathrm{m}^{3}$ ) during winter, and this may be due to this station considered away from the main drains of the lake.

The seasonal variations of total Brachionus showed that, the highest average value of total Brachionus was recorded during spring (855171 Org. $/ \mathrm{m}^{3}$ ), then decreased in summer (446779 Org. $/ \mathrm{m}^{3}$ ) and winter (204999 Org. $/ \mathrm{m}^{3}$ ), then reached to its minimum (159538 Org. $/ \mathrm{m}^{3}$ ) during Autumn. On the other hand, the spatial variations of total Brachionus recorded its highest average density at Ibn Salam Station (1387792 Org. $/ \mathrm{m}^{3}$ ), while the lowest was recorded at Bahr El-Bakar station (98495 Org. $/ \mathrm{m}^{3}$ ) due to the effect of discharged sewage then it had progressive improvement and gradual biological recovery away from this mixing point. Genus Brachionus from the most predominate rotiferan species in the River Nile and has the ability to tolerate the pollution (El-Bassat, 2002; Bedair, 2003 and Hegab, 2010). Brachionus angularis is considered the most dominant species in Lake Manzala during the study; forming $43.18 \%$ of the total Rotifera and $53.20 \%$ of the total Brachionus species. From this data we can stated that, there is a highly increasing of $B$. angularis during the study as comparing to Mageed (2008) who founded that $B$. angularis during year 2003 was 35\% of total rotifer crop. Slàděek (1983) mentioned that this species is cosmopolitan with a broad distribution in the most strongly eutrophical water. B. calyciflorus is considered the second dominant species during the study. It constituted $31.62 \%$ of the total Rotifers and $38.96 \%$ of total Brachionus species. This species considered as indicators of eutrophic condition as mentioned by Guisande \& Joja (1988). These results agreed with that obtained by Mageed (2008). B. calyciflorus recorded its highest average density during summer $286788 \mathrm{Org} . \mathrm{m}^{3}$. While, Bedair (2003) mentioned that B. calciflours flourished during winter. Branchionus angularis and B. calyciflorus formed collectively (74.80\% of the total Rotifera and $59.87 \%$ of total zooplankton). The presence of these species of Branchionus in high composition indicates eutrophication of Lake Manzala. B. urceolaris is considered the third dominant species during the study. It was formed $4.33 \%$ of the total Rotifera and $5.34 \%$ of the total Brachionus species. Syncheata sp. formed the forth dominant rotifer species forming $4.41 \%$ of the total rotifers and 3.53 $\%$ of the total zooplankton. Horellaa brehmi and Keratella tropica constituted $3.30 \%$ and $2.99 \%$ of the total rotifers and $2.64 \%$ and $2.39 \%$ of the total zooplankton, respectively.

Philodina sp. was recorded during all seasons at most stations with an average number of 11998 and formed $2.34 \%$ of the total rotifers. The highest number of Philodina sp. was recorded at El-Mataryia Station (30546 Org. $/ \mathrm{m}^{3}$ ) during Autumn 
although this Station was affected by high amount of sewage. Also, it was recorded at El-Bashtir and Bahr El-Bakar Stations which affected by New branch of Bahr ElBakar drain. This indicates that this species has the ability to tolerate different types of sewage. Khalifa (2000) recorded this genus with high density in the River Nile at stations faced to pollution. Montteiro et al. (1995) recorded Philodena sp. in the most tolerant taxa to metal concentrations in the most contaminated zone in Soda River (Portugal). This agrees with our correlation coefficient values which recorded positive correlation with nutrient salts indicating that this species present in the polluted stations and negative correlation with chloride, sodium, Potassium and calcium indicating that this species lives only in fresh water and cannot tolerate salinity. So, we can use this species as indicator for water quality. The average number of Polyarthra vulgaris was $4747 \mathrm{Org} . \mathrm{m}^{3}$ forming $0.92 \%$ of the total rotifers this low number may be due to the effect of drainage water, this agrees with that obtained by Hegab (2010), who mentioned that it flourished well when good conditions are available. This species had a strong positive correlation (0.6) with transparency because the lowest values of transparency attributed to the high concentration of suspended organic nutrient which discharge from drains. Polyarthra vulgaris occurred throughout the year. Slàdeček (1983) considered it as a permanent inhabitant of all types of fresh water, while Sharma and Pant (1985) regarded it as a good indicator of eutrophication. El Shabrawy and Khalifa (2002) mentioned that the presence of rotifers such as (Brachionus calcifloris, Polyarthra vulgaris and keratella cochlearis) which are eutrophic indicators, revealed high eutrophication. This eutrophication affects zooplankton composition, shifting the dominance from large species (Copepoda) to smaller species (Rotifera) (El-Shabrawy, 2000 \& Emam, 2006). Although, some species are recorded as rare occurrence in the lake but it considered a good indicator for water quality, e.g. Monostyla bulla. The highest peak of this species was recorded at the heavy polluted station at the discharged point of New Bahr El-Bakar drain being 7331 Org./ $\mathrm{m}^{3}$. Vice versa, other species were flourished in clean water e.g. Hexarthra oxyuris, which was recorded only at 3 stations during summer. Its lowest number was recorded at the mixing point of Bahr El-Bakar (2000 Org. $\left./ \mathrm{m}^{3}\right)$, then increased gradually away at El-Bashtir Station $\left(9333 \mathrm{Org} . / \mathrm{m}^{3}\right.$ ) and reached to the highest number at Qaboti Station (13333 Org. $\left./ \mathrm{m}^{3}\right)$.

Copepoda formed the second dominant zooplankton group forming $17.29 \%$ (average 110885 Org. $/ \mathrm{m}^{3}$ ). Mesocyclops sp. was recorded only in the eastern part of the lake forming $18.63 \%$ of the total copepods. The highest density of this species was recorded at El-Qaboti Station during spring (295272 Org. $/ \mathrm{m}^{3}$ ). Nauplius larvae were in the lake forming $65.04 \%$ of the total copepods and $11.24 \%$ of the total zooplankton. The presence of this larvae in all stations indicates that it has the ability to tolerate pollution (Emam, 2006). Copepodite stages (cyclopoid and calanoid) constituted collectively $16.33 \%$ of total copepods and $2.82 \%$ of the total zooplankton. Copepoda had a positive correlation with water temperature and transparency and a negative correlation with all nutrient salts. Also, nauplius had a strong negative correlation (-0.6) with nitrate and silicate. The low numbers of copepoda referred to the effect of pollution, while El-Enany (2009) mentioned that Copepoda was the most dominant group in Lake Nasser which attributed to the good environmental conditions of the lake. Cladocera formed only $1 \%$ (average 6444 Org. $/ \mathrm{m}^{3}$ ) of the total zooplankton. The highest average number of Cladocera was recorded during autumn (13408 Org. $/ \mathrm{m}^{3}$ ), while the lowest average was recorded during summer (111 Org. $/ \mathrm{m}^{3}$ ) This may be due to the effect of water temperature. It was represented by 7 species (Ceriodaphnia cornata, C. reticulate, Chydorus 
sphaericus, Daphnia longispina, Diaphanosoma excisum, Macrochitus spinosa and Monia micrura). C. reticulata formed the highest bulk of Cladocerans (54.36\%) followed by $D$. excisum (23.57 \%), while C. sphaericus and D. longispina recorded the lowest abundance constituting $2.59 \%$ of the total cladocerans with average 167 Org. $/ \mathrm{m}^{3}$. The highest positive correlation was recorded between Cladocera and calcium (0.7). Also, it had a positive correlation with transparency, while it had a negative correlation with nitrite and silicate. This agrees with Mageed and Heikal (2005) which recorded a positive correlation for Caldocera (Ceriodaphnia) and turbidity.

Protozoa formed $1.35 \%$ of the total zooplankton with average (8678 Org. $/ \mathrm{m}^{3}$ ). It was represented by 5 species (Arcella areniata, A. discoides, A. vulgaris, Centropyxis aculeate and Sphenoderia sp.). C. aculeate and Sphenoderia sp. formed the highest bulk of protozoans being 2273 and 2107 Org. $/ \mathrm{m}^{3}$ and representing 26.19 and $24.28 \%$ of the total Protozoa respectively. The highest number of Protozoa was recorded at the discharged point of Bahr El-Bakar Station (17333 Org. $/ \mathrm{m}^{3}$ ). This indicates that it has the ability to tolerate high pollution from drains, so, it had a positive correlation with nitrite, silicate and total phosphorus. Singh (2009) recorded similar observation in Upper Lake, India. Nematoda and Ostracoda considered minor groups of rare occurrence forming 0.12 and $0.20 \%$ of the total zooplankton with an average density 747 and $1278 \mathrm{Org} . \mathrm{m}^{3}$ respectively. The correlation coefficient showed that Nematoda had a negative correlation with oxygen and positive correlation with COD; this indicates that it can live in oxygen deficiency and in the presence of organic pollutants.

The similarity analyses between stations depending on different zooplankton species (Fig. 4) showed that, Group (A): the highest was recorded between Qaboti Station and El-Bashtir Station (75 \%) due to the small distance between them, then between these two stations and Bahr El-Bakar Station (65 \%) due to the effect of Bahr El-Bakar drain in the surrounding area. Group (B): showed moderate similarity (45\%) between El-Boom and Ibn Salam stations this may be due to that these stations are away relatively from the discharged points and then a progressive improvement and gradually biological recovery was recorded with high densities of zooplankton species.

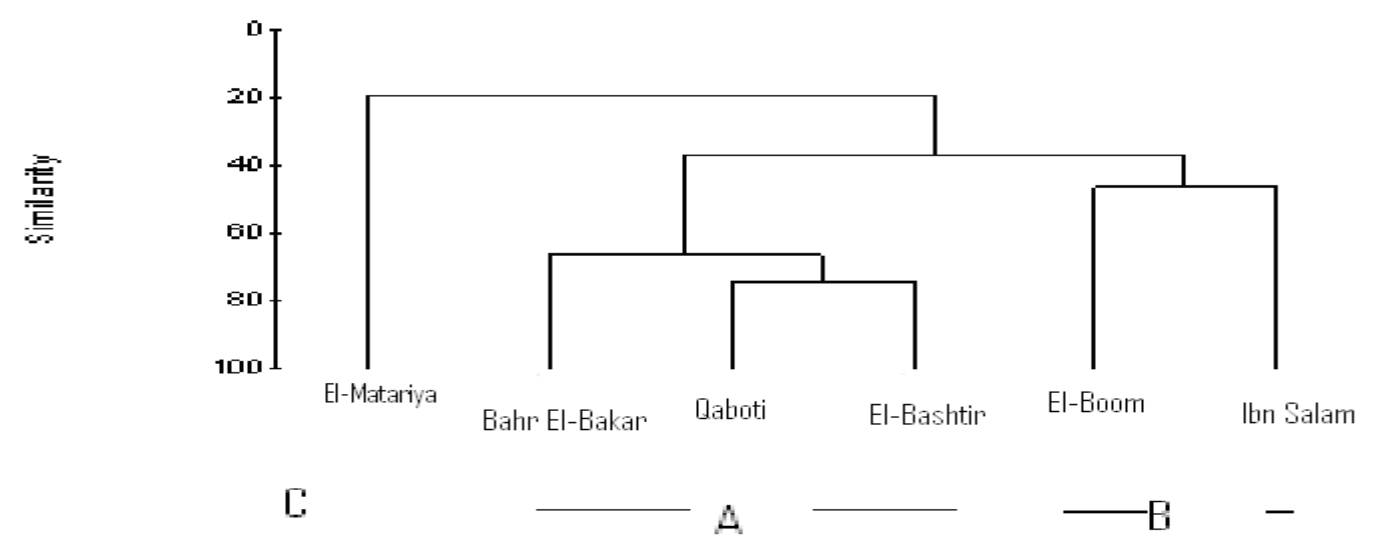

Fig. 4: Similarity between stations depending on zooplankton species during the study.

At group (C), the lowest similarity was recorded between El-Matariya Station and all the selected Stations (20\%) because it has a special biological characteristics due to it has been affected by different types of pollutants from agriculture sewage 
and human activity from El- Matariya harbor. Finally, we can conclude that, the drains play an obvious role in the distribution of zooplankton and the presence of these species of Brachionus especially Brachionus angularis and B. calyciflorus in high number of Brachionus species (7 species) and also the presence of Polyarthra vulgaris and keratella sp. indicate a high eutrophication of the lake. B. angularis, $P$. vulgaris (Rotifera), Nauplius larvae (Copepoda), Chydorus sphaericus (Cladocera), free living Nematoda and Protozoa are pollution tolerant groups of zooplankton and indicating the presence of pollution in the lake. So, we recommend that, treatment of drainage wastewater before discharging into the lake to decrease the pollutants and returning the lake again as one of the highest yield resource of fish in Egypt.

\section{REFERENCES}

Abdel-Satar, A.M. (2001). Environmental studies on the impact of the drains effluent upon the southern sector of Lake manzalh, Egypt.. Egypt. J. Aquatic Biol. \& Fish., (3) 17-30.

Ahmad, U.; S. Parveen; A.A. Khan; H.A. Kabir; H.R.A. Mola and A.H. Ganai, (2011). Zooplankton population in relation to physico-chemical factors of a sewage fed pond of Aligarh (UP), India. Biology and Medicine, 3 (2), 336-341.

American Public Health Association (APHA), 1992. Standard methods for Examination of water and wastewater, $18^{\text {th }}$ Edition. New York.

Angeli, N. (1976). Influence de la pollution sur les elements du plancton. In: Pesson P. ed.“La Pollution Oles Eaux Continentales”, Ed. Gauthier-Villars. pp. 97-133.

Bedair, S.M.E. (2003). Environmental studies on zooplankton and phytoplankton in some polluted areas of the River Nile and their relation with the feeding habit of fish. Ph.D. Thesis. Fac. Sci. Zagazig Univ.

Edmondson, W.T. (1966). Fershwater Biology. 2 nd ed. John Wiley and Sons. Inc. New York \& London, 12248 pp.

El-Bassat, R.A. (2002). Ecological studies on zooplankton communities with particular references to free living protozoa at River Nile - Egypt. Ph. D. Thesis. Fac. Sci. Zool. Dept. Ain Shams Univ., 116 PP.

El-Bokhty, E.E.B. (1996). Distribution of bottom fauna in Lake Manzalah in relation to prevailing environmental conditions. M.Sc. Thesis, Fac. Sci.. Tanta Univ..

El-Enany, H.R.(2004). Ecological studies on Lake Manzalah with special references to their water quality and sediment productivity. M.Sc. Thesis, Zool. Dept. Fac. Sci.. Al Azhar Univ.,

El-Enany, H.R. (2009). Ecological studies on planktonic and epiphytic microinvertebrates in Lake Nasser, Egypt. Ph. D. Zool. Dept. Thesis, Fac. Sci. Benha Univ., 311pp.

El-Maghraby, A.M.; Wahby, S.D. and Shaheen, A.H. (1963). The ecology of zooplankton in Lake Manzala. Notes and Memoirs, No. 70.

El-Shabrawy, G.M. (2000). Seasonal and spatial variation in zooplankton structure in Lake Nasser. II- costal area of the main channel and main Khors. J. Egypt. Acad. Soc. Environ. Develop., 1(1): 19 - 44.

El-Shabrawy, G.M. and Khalifa, N. (2002). Zooplankton abundance and community structure in the northern part and estuary of Rosetta Nile branch in relation to some environmental variables. Egypt. J. Aquatic. Biol. \& Fish., 6(4): 69 - 90.

El-Sherif, Z. M.; Aboul Ezz, S.M. and El-Komi, M.M. (1994). Effect of pollution on the productivity in Lake Manzala (Egypt). International Conference on Future Aquatic Resources in Arab Region, 159- 169. 
Emam, W. (2006). Preliminary study on the impact of water pollution in El-Rahawy drain dumping in Rosetta Nile branch on zooplankton and benthic invertebrates. M. Sc. Thesis, Zoo. Dept. Fac. Sci. Ain Shams Univ.

Galkovskaja, G.A. (1987). Planktonic rotifers and temperature. Hydrobiologia, 147: 307- 317.

Guerguess, S.K. (1993). distribution of some rotifers in the Egyptian inland waters. Bulletin of NIOF, 19: 249-275.

Guerguess, S.K. (1979). Ecological study of zooplankton and distribution of macrofauna in Lake Manzala. Ph.D.Thesis. Fac. Sci., Alexandria University, Egypt.

Guisande, C and Joja, J. (1988). Themdynamics of various species of the genus Brachionus (Rotatoria) in Guadalquiver River. Arch. Hydrobiol. 112(4): 579595.

Hegab, M.H.A.I. (2010). Ecological Studies on Zooplankton and the Relationships between them and Food and Feeding of Some Fish in Rosetta Branch (River Nile), Egypt. M.Sc. Thesis. Zoology Department, Faculty of Science, Al-Azhar University.

Khalifa N, 2000. Study on the impact of industrial wastes at Helwan on River Nile zooplankton. Ph.D. Thesis. Zoo.Dept. Fac. Sci. Cairo Univ. 141 pp.

Khalifa N, Mageed A, 2002. Some ecological aspects on the zooplankton in Lake Manzala, Egypt. Egypt. J. Zool. 38: 293-307.

Khalil, M.T. (1990a). The physical and chemical environment of Lake Manzala, Egypt. Hydrobiologia 196:193-199.

Khalil, M.T. (1990b). Plankton and primary productivity of Lake Manzala, Egypt. Hydrobiologia 196:201-207.

Khalil, M.T. and El-Awamri A.A. (1988). Plankton organisms as bio-indicators for organic pollution at the southern area (El-Genka) of Lake Manzala, Egypt. Proceeding of the first national conference on environmental studies and research. Institute of environmental studies and research. Volume 2:526-537.

Likens GE, Bormann FH, 1972. Nutrient cycling in ecosystem. In: Ecosystem, Structure and Function (E.D.J.A. Weins). Corvallis, Oregon State University Press, 25-67.

Mageed, A.A. (2008). Distribution and long-term historical changes of zooplankton assemblages in Lake Manzala (south Mediterranean sea, Egypt). Egyptian journal of aquatic research, 33 (1): 183-192.

MacLaren Engineers, Planners and Scientific Inc., 1982. Lake Manzala study. EGY/76/001-07, Final Report to Arab Republic of Egypt, Ministry of Development and New Communities and UNDP Office for Projects Execution. Toronto, Canada.

Mola, H.R.A. (2011). Seasonal and spatial distribution of Brachionus (Pallas, 1966; Eurotatoria: Monogonanta: Brachionidae), a bioindicator of eutrophication in lake El-Manzalah, Egypt. Biology and Medicine, 3 (2), 60-69.

Pontin, R.M. (1978). A key to the freshwater planktonic and semi-planktonic Rotifera of the British Isles, 178 pp. Freshwater Biological Association, Scientific Publication 38.

Sharma, P.C. and Pant, M.C. (1985). Species composition of zooplankton in two Kumaun Himalayan Lakes (UP, India). Arch. Hydrobiol. 102(3): 387-403.

Shehata, S.M.A.; Shehata, K.K,; Hussien, M.M.; Mageed, A.A. (1998a). Taxonomy, population structure, and species diversity of Rotifera in the high Dam Lake. Egypt. J. Biol. And Fish. 2(1):1-36. 
Shehata, S.M.A.; Shehata, K.K,; Hussien, M.M.; Mageed, A.A. (1998b). Taxonomical and ecological studies on some zooplankton species: Ciliata, Rhizopoda, Turbillaria and Crustac of the High Dam Lake. Egypt. J. Biol. And Fish. 2(1): 37-63.

Singh, K. (2009). Studies on the impact assessment of post Lake Management operations in Upper Lake with special reference to zooplankton. $\mathrm{PhD}$ Thesis, Department of Limnology, Barkatullah Univerisity, Bhopal, India 146p.

Slàdeček, V. (1983). Rotifers as indicator of water quality. Hydrobiologia 100:169201.

Taha, O.E. and Mageed, A.A. (2002). Spatial distribution and relationship between phytoplankton and zooplankton in Lake Nasser (Egypt) after the flood season. Egypt J. Aquat. Biol. \& Fish., 6 (4): 265-281.

Train, R.E. (1979). Quality criteria for water. Costle House Publication LTD., London, 256pp.

Van Dijk, G.M. and Van Zanten, B. (1995). Seasonal changes in zooplankton abundance in the Lower Rhine during 1987 - 1991. Hydrobiologia, 52: 29 - 38.

\section{ARABIC SUMMARY}

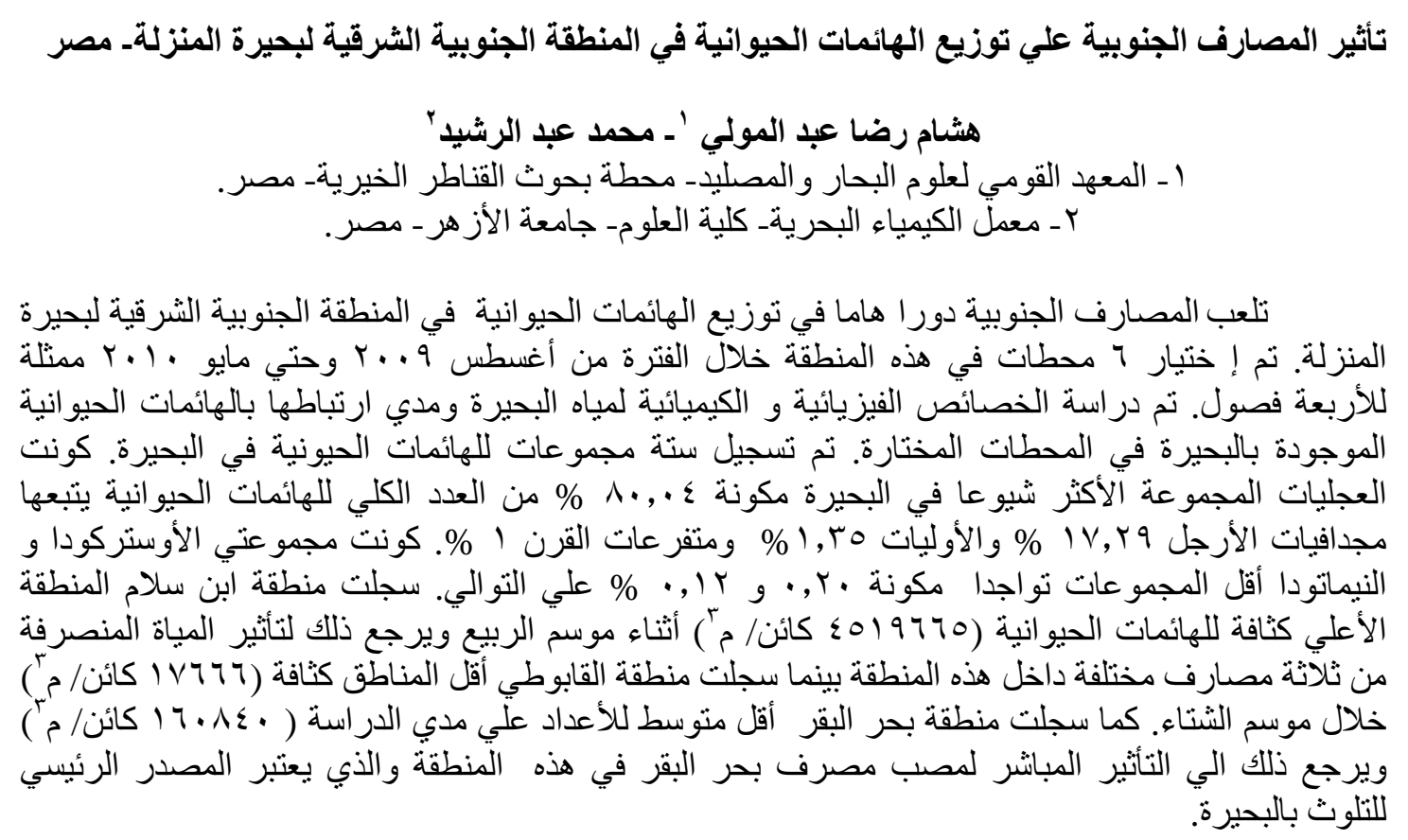

